\title{
Toxicity and Efficacy of Two Emulsifiable Concentrates of 2-Tridecanone against Red Imported Fire Ants
}

\author{
Jian Chen \\ Biological Control of Pests Research Unit, National Biological Control Laboratory, USDA-ARS, Stoneville, \\ MS, USA \\ Email: jian.chen@ars.usda.gov
}

Received 19 November 2015; accepted 23 January 2016; published 26 January 2016

Copyright (C) 2016 by author and Scientific Research Publishing Inc.

This work is licensed under the Creative Commons Attribution-NonCommercial International License (CC BY-NC). http://creativecommons.org/licenses/by-nc/4.0/ (c) (i) () Open Access

\begin{abstract}
2-tridecanone is a major constitute of defensive secretion in tawny crazy ants, Nylanderia fulva that is an ant species reported to be able to displace red imported fire ants, Solenopsis invicta in the field. 2-tridecanone was proven to be toxic to $S$. invicta. Although 2-tridecanone is commercially available, utilization of this naturally occurring compound in fire ant management has received little attention. In this study, toxicity and efficacy of two 2-tridecanone formulations were assessed against $\boldsymbol{S}$. invicta. Two emulsifiable concentrates were prepared using 2 -tridecanone as an active ingredient, vegetable oil as a solvent and polyoxyethylene tridecyl ether as a surfactant. Piperonyl butoxide (PBO) was used as a synergist in one formulation. Both formulations showed significant toxicity in laboratory bioassays. In a field trial, at application rate of $5.28 \mathrm{~mL} / \mathrm{L}$ and 14 days after mound drench treatment, $\mathbf{1 0 0 \%}$ control was achieved for formulation with PBO and $\mathbf{9 0 \%}$ control for the formulation without PBO. In conclusion, both formulations had significant efficacy against $S$. invicta. Due to the low mammalian toxicity of 2-tridecanone, no involvement of hazardous synthetic organic solvents, no phytotoxicity at applied concentrations, and relatively low cost, both formulations are promising alternatives to commercial insecticide products for fire ant mound drench. The outstanding efficacy of both formulations observed in this study warrants further research on their efficacy against other pest insects.
\end{abstract}

\section{Keywords}

Defensive Chemical, Fire Ant Control, Mound Drench 


\section{Introduction}

The red imported fire ant, Solenopsis invicta Buren, is a significant pest affecting humans, wildlife, crops, and livestock [1]. Synthetic insecticides are commonly used in fire ant management [2] [3]. Insecticide products exert toxic effect on fire ants through either contact or bait ingestion. Contact based products are applied using the following methods based on their formulations: 1) liquids for individual mound drench, 2) granules for mound surface treatment, which is followed by water application in order to facilitate the active ingredient to reach the target, 3) granules or dusts for mound surface treatment without applying water, 4) liquid or aerosol for mound injection, 5) liquids or granules for broadcast over the entire treatment area, and 6) liquid for Immersion/dip treatment to treat containerized nursery stock and balled-and-burlapped plants for quarantine purpose [4]. Baits are usually applied by broadcasting; however they can also be used to treat individual mounds [3]. Contact based products usually provide faster control than bait because baits require time for ants to trophallactically spread the toxicant within the colony. In some situations, contact based products are the only option if a quick control is desired.

Numerous synthetic insecticides have been registered for fire ant control, particularly in contact based products [3]. Due to the ever increasing concern to the negative impact of synthetic insecticides on human health and environment, the use of more toxicologically and environmentally benign chemicals is highly desirable. Chemicals from natural products are believed to be more desirable insecticides than conventional synthetic insecticides, due to their rapid environmental biodegradable property and lower toxicity to natural enemies, humans and other mammals [5] [6].

Plants have been a major source of natural insecticides [5] [6]. Well-known examples include pyrethrins from Chrysanthemum cinerariifolium in Asteraceae family, nicotine and related alkaloids from Nicotiana spp. in Solanaceae family, rotenone from Lonchocarpus spp. and Derris spp. in Fabaceae family, sabadilla from Schoenocaulon spp. in Melanthiaceae family, azadirachtin from Azadirachta indica in Meliaceae family (Neem), and essential oils and their derivatives in plants from numerous families, such as Myrtaceae, Lauraceae, Rutaceae, Lamisceae, Asteraceae, Apiaceae, Cupressaceae, Poaceae, Zingiberaceae and Piperaceae [6]. Several plant-derived compounds have been tested against red imported fire ants, such as d-limonene, pyrethrins, rotenone, pine oil and turpentine [3] [7].

Another potential source of natural toxins against fire ants is the defensive chemicals in other ants. Chemical defense is common in ants [8] [9]. As one of primary defense mechanisms, defensive secretions often determine the outcome of interspecific competition between ants [10]-[13]. Many ants compete with S. invicta [14]-[24] with one prominent example being the tawny crazy ant, Nylanderia fulva (Mayr). Tawny crazy ant is an ant species reported to be able to displace S. invicta in the field [13]. Tawny crazy ant workers produce formic acid in their poison glands and methylketones and alkanes in Dufour glands. Of these compounds, 2-tridecanone has the smallest $\mathrm{LD}_{50}$ value against $S$. invicta (18.51 to $24.67 \mu \mathrm{g} / \mathrm{ant}$ ) [25], and may be a promising naturally occurring toxin that can be used in fire ant management. In this study, two emulsifiable concentrates were prepared using 2-tridecanone as an active ingredient, soybean oil as a solvent and polyoxyethylene tridecyl ether as an emulsifier. Since piperonyl butoxide (PBO) was found to improve the toxicity of 2-tridecanone against imported fire ants (Chen, unpublished data), PBO was used as a synergist in one formulation. For both formulations, contact and immersion toxicity were determined in the laboratory and efficacy as mound drench treatment was assessed in the field.

\section{Materials and Methods}

\subsection{Insects}

Red imported fire ant colonies were collected from Washington County, Mississippi. Colonies were separated from soil using water dripping method [26] and reared in a plastic tray $(44.5 \times 60.0 \times 13.0 \mathrm{~cm})$. The social form of S. invicta colonies was determined using PCR on Gp-9 alleles [27]. All ants used in laboratory bioassays were from monogyne colonies; however, social form of colonies in field mound drench treatment was not determined. The same diet (10\% sugar water and house crickets) was used for rearing all laboratory colonies. Colonies were maintained in a rearing room at $25^{\circ} \mathrm{C}, 80 \% \mathrm{R}$. H. with a $12: 12$ (L:D) photoperiod.

\subsection{Formulations}

Two emulsifiable concentrates were prepared using 2-tridecanone as an active ingredient, vegetable oil as a sol- 
vent and polyoxyethylene tridecyl ether as an emulsifier. Surfactants are commonly used in insecticide formulations as adjuvants to enhance the performance of the insecticidal active ingredients. However, surfactants may have their own intrinsic detrimental effect on insects. The responses of the red imported fire ant to polyoxyethylene tridecyl ether surfactants (Ethox Chemical, LLC, Greenville, SC, USA) and their relationships to the hydrophilic-lipophilic balance (HLB) numbers have been investigated. Polyoxyethylene tridecyl ether surfactants have intrinsic toxicity against $S$. invicta. Their contact toxicity was found to be inversely correlated with HLB numbers (Chen, unpublished data). Polyoxyethylene tridecyl ether surfactant with HLB number 7.9 (the smallest HLB number available for this particular type of surfactant) was used in both formulations. The compositions of two formulations are shown in Table 1. Since piperonyl butoxide (PBO) was found to improve the toxicity of 2-tridecanone against imported fire ants in the laboratory (Chen, unpublished data), PBO was used as a synergist in one formulation.

\subsection{Laboratory Bioassays}

Toxicity in soil treatment. About $1 \mathrm{~kg}$ of soil was collected from a fire ant mound, dried in oven under $100^{\circ} \mathrm{C}$ for $24 \mathrm{~h}$, and then sieved through a \#35 sieve to remove debris and large particles. Ten grams of dry soil was placed in a 20-mL glass scintillation vial (Thermo Fisher Scientific Inc., Waltham, Massachusetts, USA) and mixed with $0.8 \mathrm{ml}$ water. Soil in vial was then pressed firmly using a wood stick. Twenty workers of various sizes (0.4 to $4.3 \mathrm{mg}$ ) were placed in the vial. Ants were allowed to settle down and dig for $12 \mathrm{~h}$ before $1.0 \mathrm{ml}$ water solution of a test formulation was added into the vial. Glass vials were loosely capped and then placed in a 30 (RC water bath. Dead ants were counted $24 \mathrm{~h}$ after soil was treated. Five concentrations were tested, including $0.50 \%$, 0.25\%, 0.14\%, 0.06\% and 0.03\% (emulsifiable concentrate dissolved in water w/v). Water was used as a control. Three colonies were used. There were 4 replicates for each concentration. The LC $_{50}$ value was reported as mg test material per gram soil.

Toxicity in immersion treatment. Mortalities of worker ants after being immersed in water solutions of a tested formulation were determined. Twenty workers of various sizes were treated by immersing ants in $5 \mathrm{ml}$ solution in a $20-\mathrm{ml}$ glass vial. The glass vials were placed in a $30^{\circ} \mathrm{C}$ water bath. Treatment times included $0.5,1.0,2.0$, 3.0, 4.0 and $5.0 \mathrm{~h}$. After treatment, ants were transferred onto a filter paper and then into a 20-ml glass vial with a piece of moisten filter paper. The vial was loosely capped and kept at room temperature $\left(\sim 23^{\circ} \mathrm{C}\right)$. Dead ants were counted $24 \mathrm{~h}$ after ants were treated. Two concentrations, $0.01 \%$ and $0.1 \%(\mathrm{w} / \mathrm{v})$, were tested for both formulations. Three colonies were used and there were 4 replicates for each concentration. Immersion in water was used as a control. Since ants can float on the water surface, the immersion procedure was slightly modified. After 20 ants were placed in the vial, the vial was completely filled with distilled water and capped with a petri dish. After all ants in the vial were immobilized, the petri dish was removed.

\subsection{Field Experiment-Mound Drench}

Both formulations were tested as mound drench along with water-only as a negative control and registered insecticide, Entrust ${ }^{\circledR}$ SC Naturalyte ${ }^{\circledR}$ Insect Control (22.5\% spinosad, Dow AgroSciences LLC, Indianapolis, Indiana), as a positive control. Two applications rates, $5.28 \mathrm{~mL} / \mathrm{L}$ and $2.64 \mathrm{~mL} / \mathrm{L}$, were tested. For mounds less than $20.32 \mathrm{~cm}$ in diameter, $3785 \mathrm{ml}$ of emulsion was used for each mound. For mounds $20.32 \mathrm{~cm}$ or larger, 7570

Table 1. Composition of two emulsifiable concentrates of 2-tridecanone.

\begin{tabular}{ccc} 
Formulation & Component & Percentage (w/w) \\
\hline A & 2-tridecanone & 30 \\
& Soybean oil & 30 \\
B & Ethal TDA & 2 2-tridecanone \\
& Soybean oil & 20 \\
& Ethal TDA & 20 \\
\end{tabular}


$\mathrm{ml}$ of emulsion was used. The Entrust ${ }^{\circledR}$ SC was applied per label instruction $(0.39 \mathrm{~mL} / \mathrm{L})$. The final spinosad concentration in the suspension was $0.0088 \%$. The study was conducted in Leroy Percy Wildlife Management Area Hollandale, MS in August and September 2014. Colonies on the road side (highway 12) were used. A colony was randomly assigned to a treatment or control. Each treatment or control had 15 to 16 replicates (mounds). Mounds were measured one week before the experiment. The widest aspect of a mound was recorded as its size. All mounds had a minimum size of $10 \mathrm{~cm}$ and all mounds were minimum $4 \mathrm{~m}$ apart. One day before treatment, ant activity was evaluated for each mound between 7:00 am and 9:00 am. A wood rod was inserted into the center of the mound to a depth of $10 \mathrm{~cm}$. After 10 seconds, the rod was removed from the mound and ants on the rod were dislodged into a container and counted. Treatments or controls were applied between 7:00 am and 10:00 am, when ants were in the upper part of the mound. All treatment or controls were applied using a 10 -L plastic container. About $10 \%$ of the dilution or water was first applied around the perimeter of the mound and the remaining volume was directly applied on the mound. Ant activities were then measured 1, 3, 8, and 14 days after treatment. Relocated mounds that were formed after treatment and within a 1.5-m radius of the original mound were inspected, their sizes and ant activity measured. Mounds were scored according to a system (Table 2) adapted from Vogt et al. [7].

\subsection{Data Analysis}

PoloPlus (Version 2.0, LeOra Software, Petaluma, California, USA) was used to estimate $\mathrm{LC}_{50}$ and $\mathrm{LT}_{50}$ with $95 \%$ confidence interval (CIs). The relative toxicity ratio with their upper and lower 95\% confidence limits was used to evaluate the significance of difference between $\mathrm{LC}_{50}$ values. The significance was set at $\mathrm{P}=0.05$ probability level. If the $95 \%$ confidence interval of the ratio between two $L_{50}$ values include 1 , they were not considered significantly different [28]. For field experiment, analysis of variance (PROC GLM; SAS Institute 2008) was performed on mound score and the percentage reduction in ant activity. Means were separated using Tukey's Multiple Comparison Test $(\mathrm{P}<0.05)$. Percentage reduction in ant activity was calculated using the following equation: percentage reduction $=(($ pre-treatment ant count - post-treatment ant count $) /$ pre-treatment ant count $) \times 100$. If there were relocated colonies, the sum of ant count for all colonies was used as the post-treatment ant count.

\section{Results}

\subsection{Laboratory Bioassay}

Toxicity in soil treatment. The $\mathrm{LC}_{50}$ values for both formulations are presented in Table $3 . \mathrm{LC}_{50}$ value ranged from 0.066 to $0.102 \mathrm{mg} / \mathrm{g}$ for formulation A and 0.039 to $0.070 \mathrm{mg} / \mathrm{g}$ for formulation B. For both formulations, $\mathrm{LC}_{50}$ values were significantly different among three colonies. For formulation A, it needed $0.214 \mathrm{mg} / \mathrm{g}$ in soil to cause $100 \%$ mortality for colony 1 and 2 and $0.430 \mathrm{mg} / \mathrm{g}$ for colony 3 . For formulation B, it needed 0.107 $\mathrm{mg} / \mathrm{g}$ to cause $100 \%$ mortality for colony 2 and $0.214 \mathrm{mg} / \mathrm{g}$ for colonies 1 and 3 .

Toxicity in immersion treatment. The $\mathrm{LT}_{50}$ values for both formulations are shown in Table 4. Formulation B had higher immersion toxicity than formulation $\mathrm{A}$. Three data sets were not adequate for calculating $\mathrm{LT}_{50}$ values: formulation A at $0.1 \mathrm{~mL} / \mathrm{L}$ for colony 1 and formulation B at $0.1 \mathrm{~mL} / \mathrm{L}$ for colony 1 and at $1.0 \mathrm{~mL} / \mathrm{L}$ for colony 2. Within a colony, all available pairwise comparison indicated that formulation $\mathrm{B}$ always had smaller $\mathrm{LT}_{50}$ value than formulation A at the same concentration level. For each formulation, the higher its concentration, the

Table 2. Score system used to evaluate the effect of mound drench treatment*.

\begin{tabular}{ccc}
\hline Score & Treated mound alive? & Number of new mounds $<\mathbf{1 . 5}$ m away \\
\hline 1 & no & 0 \\
2 & no & 1 \\
3 & no & 2 \\
4 & yes & 0 \\
5 & yes & 1 \\
6 & yes & 2 \\
\hline
\end{tabular}

\footnotetext{
*: Adapted from vogt et al. [7].
} 
Table 3. Toxicity of two formulations in soil treatment bioassay.

\begin{tabular}{cccccc}
\hline Colony & Formulation & $\mathbf{L C}_{\mathbf{5 0}}(\mathbf{m g} / \mathbf{g})$ & $\mathbf{9 5 \%} \mathbf{C I}$ & Slope $( \pm$ SE) & $\boldsymbol{X}^{\mathbf{2}}$ \\
\hline 1 & A & 0.066 & $0.056-0.074$ & $5.072 \pm 0.73$ & 8.79 \\
& B & 0.047 & $0.040-0.054$ & $4.64 \pm 0.62$ & 16.18 \\
2 & A & 0.089 & $0.055-0.110$ & $4.47 \pm 0.89$ & 28.64 \\
& B & 0.039 & $0.034-0.043$ & $6.16 \pm 0.89$ & 3.88 \\
& A & 0.102 & $0.077-0.123$ & $3.52 \pm 0.46$ & 24.24 \\
& B & 0.07 & $0.061-0.078$ & $5.18 \pm 0.65$ & 17.78 \\
\hline
\end{tabular}

Table 4. Toxicity of two formulations in immersion treatment bioassay.

\begin{tabular}{|c|c|c|c|c|c|c|}
\hline Colony & Formulation & Conc $(\%, w / v)$ & $\mathbf{L T}_{50}(\mathrm{~h})$ & 95\% CI & Slope $( \pm$ SE) & $X_{2}$ \\
\hline \multirow[t]{4}{*}{1} & A & 0.1 & 1.32 & $1.18-1.47$ & $6.33 \pm 0.55$ & 35.45 \\
\hline & & 0.01 & — $^{*}$ & - & - & - \\
\hline & B & 0.1 & 1.17 & $0.91-1.40$ & $7.34 \pm 0.75$ & 81.22 \\
\hline & & 0.01 & - & - & - & - \\
\hline \multirow[t]{4}{*}{2} & A & 0.1 & 0.88 & $0.79-0.96$ & $4.72 \pm 0.43$ & 15.66 \\
\hline & & 0.01 & 1.28 & $1.15-1.41$ & $5.01 \pm 0.39$ & 26.25 \\
\hline & B & 0.1 & - & - & - & - \\
\hline & & 0.01 & 0.85 & $0.78-0.92$ & $6.04 \pm 0.63$ & 16.45 \\
\hline \multirow[t]{4}{*}{3} & A & 0.1 & 0.92 & $0.77-1.08$ & $4.23 \pm 0.36$ & 52.44 \\
\hline & & 0.01 & 1.07 & $0.98-1.17$ & $4.94 \pm 0.40$ & 17.66 \\
\hline & B & 0.1 & 0.6 & $0.54-0.65$ & $6.44 \pm 0.82$ & 2.34 \\
\hline & & 0.01 & 0.95 & $0.86-1.04$ & $4.93 \pm 0.43$ & 19.6 \\
\hline
\end{tabular}

${ }^{*}: \mathrm{LT}_{50}$ value could not be determined using PoloPlus.

smaller its $\mathrm{LT}_{50}$ value. Mean mortalities of workers in immersion bioassay are shown in Figure 1. For formulation A, except colony 3 at the concentration of $0.01 \%$ that needed $2 \mathrm{~h}$ to cause $100 \%$ mortality, all other treatments need $3 \mathrm{~h}$, whereas, for formulation B, colony 2 at $0.1 \%$ only needed $1 \mathrm{~h}$, other three treatments needed $2 \mathrm{~h}$ and only two treatments at $0.01 \%$ need $3 \mathrm{~h}$.

\subsection{Field Experiment-Mound Drench}

Both formulations caused significant ant activity reduction. Fourteen days after treatment, all treatments including two formulations and the positive control all had significant reduction in ant activity (Table 5) and smaller mound scores (Table 6) than the water control. Although the difference among those treatments were not statistically significant, only formulation B at $5.28 \mathrm{~mL} / \mathrm{L}$ achieved a complete control $(100 \%$ activity reduction and mound score of 1.0). The positive control (Entrust ${ }^{\circledR}$ SC) had $88.06 \%$ activity reduction and 1.40 mound score and the negative control, water drench, had $25.50 \%$ activity reduction and 3.27 mound score. All treatment caused satellite mounds; however, only formulation B at $5.28 \mathrm{~mL} / \mathrm{L}$, all satellite mounds died out within 14 days.

\section{Discussion}

Due to the concern about the negative environmental impact of traditional synthetic insecticides, homeowners have an ever-increasing interest in the use of less toxic or "organic" products for fire ant control. Numerous naturally occurring compounds and materials have been investigated for their toxicity and repellency against fire ants [29]-[33]. Mortality was observed when red imported fire ants were exposed to plant essential oils, such as 

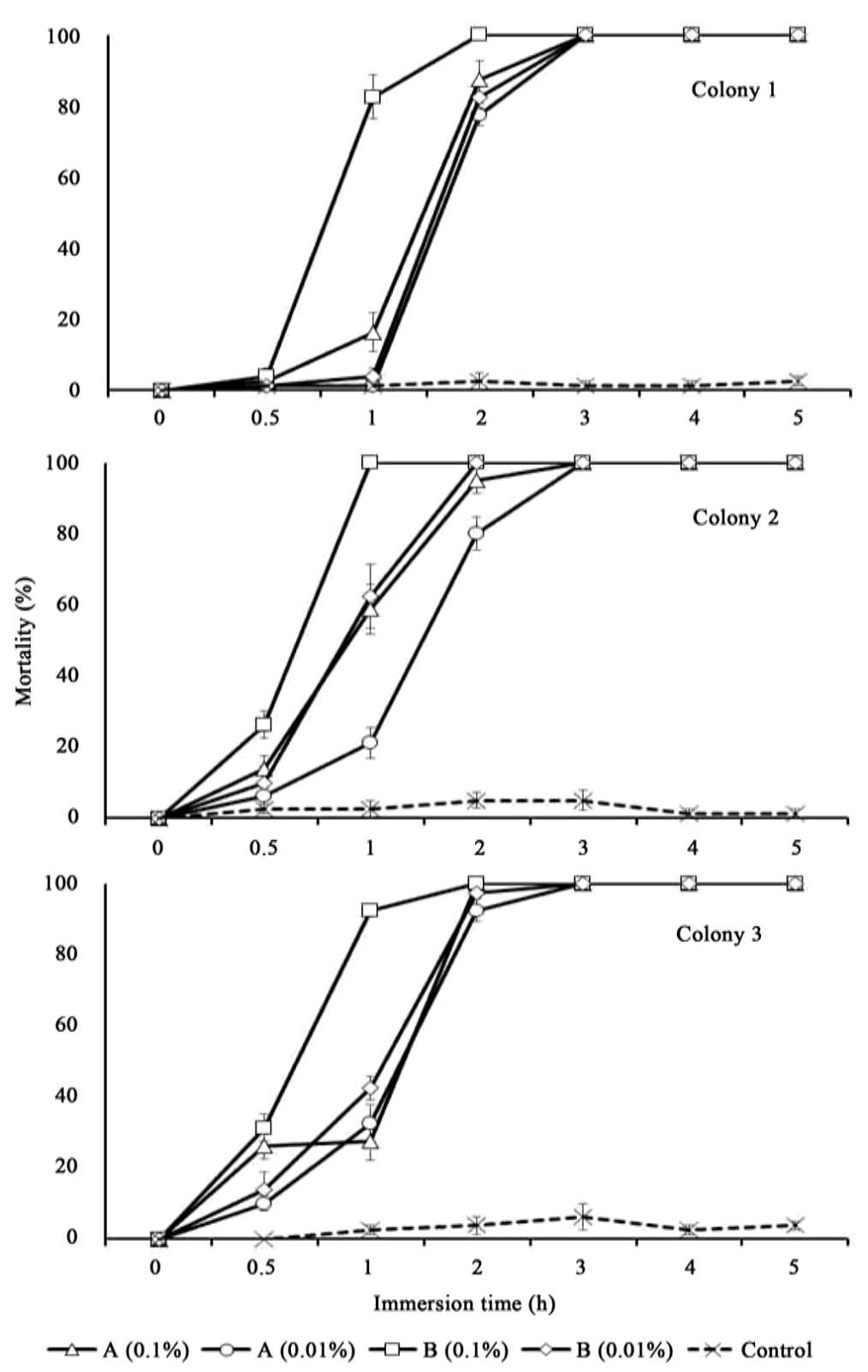

Figure 1. Mean mortality (\%) of S. invicta workers in immersion bioassay.

Table 5. Ant activity reduction after mound drench treatment.

\begin{tabular}{ccccc}
\hline \multirow{2}{*}{ Formulation } & \multicolumn{4}{c}{ Ant activity reduction (\%, mean $\pm \mathbf{S E})^{*}$} \\
\cline { 2 - 5 } & $\mathbf{1}$ day & $\mathbf{3}$ day & $\mathbf{8}$ day & $\mathbf{1 4}$ day \\
\hline $\mathrm{A}(5.28 \mathrm{~mL} / \mathrm{L})$ & $88.98 \pm 5.25 \mathrm{a}$ & $77.20 \pm 8.88 \mathrm{a}$ & $73.06 \pm 10.13 \mathrm{a}$ & $88.03 \pm 8.98 \mathrm{a}$ \\
$\mathrm{A}(2.64 \mathrm{~mL} / \mathrm{L})$ & $79.39 \pm 6.50 \mathrm{a}$ & $73.71 \pm 11.55 \mathrm{a}$ & $71.38 \pm 16.73 \mathrm{a}$ & $78.05 \pm 8.49 \mathrm{a}$ \\
Entrust $^{\circledR} \mathrm{SC}{ }^{* *}$ & $80.03 \pm 6.42 \mathrm{a}$ & $89.24 \pm 5.89 \mathrm{a}$ & $90.31 \pm 6.61 \mathrm{a}$ & $88.06 \pm 8.79 \mathrm{a}$ \\
$\mathrm{B}(5.28 \mathrm{~mL} / \mathrm{L})$ & $98.81 \pm 1.19 \mathrm{a}$ & $81.62 \pm 12.93 \mathrm{a}$ & $96.00 \pm 4.00 \mathrm{a}$ & $100.00 \pm 0.00 \mathrm{a}$ \\
$\mathrm{B}(2.64 \mathrm{~mL} / \mathrm{L})$ & $88.85 \pm 5.33 \mathrm{a}$ & $75.16 \pm 9.03 \mathrm{a}$ & $79.54 \pm 11.13 \mathrm{a}$ & $96.28 \pm 2.53 \mathrm{a}$ \\
Water & $31.14 \pm 17.99 \mathrm{~b}$ & $30.08 \pm 12.57 \mathrm{~b}$ & $12.84 \pm 19.62 \mathrm{~b}$ & $25.50 \pm 16.19 \mathrm{~b}$ \\
\hline
\end{tabular}

*: Under the same day, means followed by the different letter are significantly different $(P<0.05){ }^{* *}$ : The Entrust ${ }^{\circledR}$ SC was applied per label instruction $(0.39 \mathrm{~mL} / \mathrm{L})$. 
Table 6. Mean mound score after mounds were drenched with two formulations, Entrust SC and water.

\begin{tabular}{ccccc}
\hline \multirow{2}{*}{ Formulation } & \multicolumn{4}{c}{ Mound score (mean \pm SE) $^{*}$} \\
\cline { 2 - 4 } & $\mathbf{1}$ day & $\mathbf{3}$ day & $\mathbf{8}$ day & $\mathbf{1 4}$ day \\
\hline $\mathrm{A}(5.28 \mathrm{~mL} / \mathrm{L})$ & $2.13 \pm 0.36 \mathrm{bc}$ & $2.53 \pm 0.42 \mathrm{ab}$ & $2.13 \pm 0.38 \mathrm{~b}$ & $1.40 \pm 0.21 \mathrm{~b}$ \\
$\mathrm{~A}(2.64 \mathrm{~mL} / \mathrm{L})$ & $3.27 \pm 0.33 \mathrm{ab}$ & $2.73 \pm 0.45 \mathrm{ab}$ & $1.60 \pm 0.29 \mathrm{~b}$ & $2.07 \pm 0.37 \mathrm{~b}$ \\
Entrust $^{\circledR} \mathrm{SC}^{* *}$ & $3.40 \pm 0.32 \mathrm{a}$ & $2.07 \pm 0.42 \mathrm{ab}$ & $1.20 \pm 0.15 \mathrm{~b}$ & $1.40 \pm 0.34 \mathrm{~b}$ \\
$\mathrm{~B}(5.28 \mathrm{~mL} / \mathrm{L})$ & $1.31 \pm 0.20 \mathrm{c}$ & $1.44 \pm 0.16 \mathrm{~b}$ & $1.06 \pm 0.06 \mathrm{~b}$ & $1.00 \pm 0.00 \mathrm{~b}$ \\
$\mathrm{~B}(2.64 \mathrm{~mL} / \mathrm{L})$ & $2.07 \pm 0.37 \mathrm{bc}$ & $2.13 \pm 0.41 \mathrm{ab}$ & $1.60 \pm 0.27 \mathrm{~b}$ & $1.27 \pm 0.21 \mathrm{~b}$ \\
Water & $4.07 \pm 0.07 \mathrm{a}$ & $3.40 \pm 0.35 \mathrm{a}$ & $3.33 \pm 0.36 \mathrm{a}$ & $3.27 \pm 0.37 \mathrm{a}$ \\
\hline
\end{tabular}

*: Under the same day, means followed by the different letter are significantly different $(P<0.05) .{ }^{* *}$ : The Entrust ${ }^{\circledR}$ SC was applied per label instruction $(0.39 \mathrm{~mL} / \mathrm{L})$.

citrus oil [7], essential oil from Cinnamomum osmophloeum leaf [32] and mint oil [31]. Efficacy of several plant oil-containing products was demonstrated in mound drench treatment, including Garden-Ville Soil Conditioner (30\% citrus oil) [7], Citrex ${ }^{\mathrm{TM}}$ (78.2\% d-limonene), Concern ${ }^{\circledR}$ (5.8\% d-limonene), Exxant (14.2\% turpentine plus $0.2 \%$ ammonia) and TFA Super-Kill ${ }^{\mathrm{TM}}$ (89\% pine oil) [33]. Unfortunately field efficacy data are available for only few products, such as Garden-Ville Soil Conditioner (Gardenville Fertilizer Co., San Antonio, TX) [7] and Citrex ${ }^{\circledR}$ Fire Ant Killer (EnviroSafe Labs, Conroe, TX) [34]. For Citrus oil products (d-limonene as the active ingredient), significantly high application rate was recommended, such as $62.42 \mathrm{ml} / \mathrm{L}$ for Citrex ${ }^{\circledR}$ Fire Ant Killer and $47 \mathrm{ml} / \mathrm{L}$ for Garden-Ville Soil Conditioner. Citrex ${ }^{\circledR}$ Fire Ant Killer was observed to cause discoloration and death of common turf grasses like Bermuda and St. Augustine grass. In this study, both 2-Tridecanoneformulations have achieved significant fire ant control at a very low application rate $(5.28 \mathrm{~mL} / \mathrm{L})$. At this application rate, no phytotoxicity to the grasses was observed in the field experiment. Based on the price of each component at time of purchase, the cost per mound is $\$ 0.58$ for formulation $\mathrm{A}$ and $\$ 0.57$ for formulation $\mathrm{B}$, which are less expensive than many commercially available mound drench products [7] [34]-[36].

Like d-limonene, 2-tridecanone is also widely used as a flavor/fragrance additive in cosmetics and foods, indicating its low human toxicity. Although, d-Limonene has been designated as a chemical with low toxicity based upon lethal dose $\left(\mathrm{LD}_{50}\right)$ and repeated-dose toxicity studies when administered orally to animals, skin irritation or sensitizing potential was reported following widespread use of this agent in various consumer products [37]. Vapor pressure for 2-tridecanone and d-limonene is 0.0164 and $1.96 \mathrm{mmHg}$ at $25^{\circ} \mathrm{C}$ respectively, indicating that 2-tridecanone is much less volatile than d-limonene, indicating that 2-tridecanone will cause less potential vapor hazard in work places. Concerns about pesticide safety usually involved two aspects, the environment and end-user. To protect the environment the general trend is to use reduced levels of active ingredients. This trend creates a need for pesticide formulation with improved efficacy at low application rate. To protect the end-user, environmentally safe formulations that eliminate organic solvent-based formulations are needed. The two new formulations reported here do not use any synthetic organic solvents.

Insecticidal property of 2-tridecanone has been demonstrated in many arthropod pests [38]-[44]. Naturally occurring 2-tridecanone was first identified in the wild tomato Lycopersicon hirsutum f. glabratum [41]. It is possible to obtain about $2.4 \mathrm{mg}$ of 2-tridecanone from one gram of wild tomato leaflets [45]. 2-tridecanone was found in many other plants, such as coconut, palm, American cranberry, rabbiteye blurberry, raspberry [46]. Another potential significant natural source of 2-tridecanone is Eclipta indica L. (Asteraceae). 2-Tridecanone is the most abundant constituent in the essential oil from E. indica (89.7\%) [47]. Formulations have been prepared using the leaves of wild tomato plants and the persistence of -2-tridecanone was evaluated on the leaves of seven vegetables [48]. Half-life $\left(\mathrm{T}_{1 / 2}\right)$ of 2-tridecanone was $1.5 \mathrm{~h}$ on squash leave and $4.0 \mathrm{~h}$ on broccoli leaves, indicating a short persistence 2-tridecanone on the vegetable leaves [48].

Like synthetic insecticides, naturally occurring toxins may also have potential undesired effects on non-target organisms. For example, pyrethrins, well known natural insecticides derived from Chrysanthemum cinerariifolium, are extremely toxic to fish and beneficial insects such as bees [49]. D-limonene, active ingredient of Citrus oil products for fire ant control, shows high acute toxicity to fish and Daphnia [50]. The material safety data sheet (MSDS) shows that 2-tridecanone is also very toxic to aquatic life with long lasting effects. So every effort 
must be made to avoid contaminating water in the application of these two formulations.

\section{Acknowledgements}

We thank Dr. Andrew Li, USDA-ARS, Beltsville, MD, and Dr. Carlos Blanco, USDA-APHIS Biotechnology Regulatory Services, Riverdale, MD for critical reviews of an early version of the manuscript. We thank Mr. Leon Hicks for his technical assistance. Mention of trade names or commercial products in this publication is solely for the purpose of providing specific information and does not imply recommendation or endorsement by the US Department of Agriculture.

\section{References}

[1] Vinson, S.B. (2013) Impact of the Invasion of the Imported Fire Ant. Insect Science, 20, 439-455. http://dx.doi.org/10.1111/j.1744-7917.2012.01572.x

[2] Williams, D.F., Collins, H.L. and Oi, D.H. (2001) The Red Imported Fire Ant (Hymenoptera: Formicidae): An Historical Perspective of Treatment Programs and the Development of Chemical Baits for Control. American Entomologist, 47, 146-159. http://dx.doi.org/10.1093/ae/47.3.146

[3] Drees, B.M., Calixto, A.A. and Nester, P.R. (2013) Integrated Pest Management Concepts for Red Imported Fire Ants Solenopsis invicta (Hymenoptera: Formicidae). Insect Science, 20, 420-438. http://dx.doi.org/10.1111/j.1744-7917.2012.01552.x

[4] Callcott, A.A.M. (2006) Imported Fire Ant 2007: Quarantine Treatments for Nursery Stock and Other Regulated Articles. USDA, Animal and Plant Health Inspection Service, Program Aid No. 1904, 28 p.

[5] Copping, L.G. and Duke, S.O. (2007) Natural Products That Have Been Used Commercially as Crop Protection Agents. Pest Management Science, 63, 524-554. http://dx.doi.org/10.1002/ps.1378

[6] Mann, R.S. and Kaufman, P.E. (2012) Natural Product Pesticides: Their Development, Delivery and Use against Insect Vectors. Mini-Reviews in Organic Chemistry, 9, 185-202. http://dx.doi.org/10.2174/157019312800604733

[7] Vogt, J., Shelton, T.G., Merchant, M.E., Russell, S.A., Tanley, M.J. and Appel, A. (2002) Efficacy of Three Citrus Oil Formulations against Solenopsis invicta Buren (Hymenoptera: Formicidae), the Red Imported Fire Ant. Journal of Agricultural and Urban Entomology, 19, 159-171.

[8] Leclercq, S., de Biseau, J.C., Braekman, J.C., Daloze, D., Quinet, Y., Luhmer, M., Sundin, A. and Pasteels, J.M. (2000) Furanocembranoid Diterpenes as Defensive Compounds in the Dufour Gland of the Ant Crematogaster brevispinosa Rochai. Tetrahedron, 56, 2037-2042. http://dx.doi.org/10.1016/S0040-4020(00)00113-7

[9] Leclercq, S., Braekman, J.C., Daloze, D. and Pasteels, J.M. (2000) The Defensive Chemistry of Ants. Progress in the Chemistry of Organic Natural Products, 79, 115-229. http://dx.doi.org/10.1007/978-3-7091-6341-2_2

[10] Andersen, A.N., Blum, M.S. and Jones, T.H. (1991) Venom Alkaloids in Monomorium "rothsteini” Forel Repel Other Ants: Is This the Secret to Success by Monomorium in Australian ant Communities. Oecologia, 88, 157-160. http://dx.doi.org/10.1007/BF00320805

[11] Greenberg, L., Kabashima, J.N., Allison, C.J., Rust, M.K., Klotz, J.H., Hurvois, J.P. and Paine, T.D. (2008) Lethality of Red Imported Fire Ant Venom to Argentine Ants and Other Ant Species. Annals of the Entomological Society of America, 101, 1162-1168. http://dx.doi.org/10.1603/0013-8746-101.6.1162

[12] Sorrells, T.R., Kuritzky, L.Y., Kauhanen, P.G., Fitzgerald, K., Sturgis, S.J., Chen, J., Dijamco, C.A., Basurto, K.N. and Gordon, D.M. (2011) Chemical Defense by the Native Winter Ant (Prenolepis imparis) against the Invasive Argentine Ant (Linepithema humile). PLoS ONE, 6, e18717. http://dx.doi.org/10.1371/journal.pone.0018717

[13] Lebrun, E.G., Jones, N.T. and Gilbert, L.E. (2014) Chemical Warfare among Invaders: A Detoxification Interaction Facilitates an Ant Invasion. Science, 343, 1014-1017. http://dx.doi.org/10.1126/science.1245833

[14] Whitcomb, W.H., Bhatkar, A. and Nickerson, J.C. (1973) Predators of Solenopsis invicta Queens Prior to Successful Colony Establishment. Environmental Entomology, 2, 1101-1103. http://dx.doi.org/10.1093/ee/2.6.1101

[15] Nickerson, J.C., Whitcomb, W.H., Bhatkar, A.P. and Naves, M.A. (1975) Predation on Founding Queens of Solenopsis invicta by Workers of Conomyrma insana. Florida Entomologist, 58, 75-82. http://dx.doi.org/10.2307/3493384

[16] Lammers, J.M. (1987) Mortality Factors Associated with the Founding Queens of Solenopsis invicta Buren, the Red Imported Fire Ant: A Study of the Native Ant Community in Central Texas. Master’s Thesis, Texas A\&M University, College Station, $206 \mathrm{p}$.

[17] Stein, M.B. and Thorvilson, H.G. (1989) Ant Species Sympatric with the Red Imported Fire Ant in Southeastern Texas. Southwestern Entomology, 14, 225-231.

[18] Nichols, B.J. and Sites, R.W. (1991) Ant Predators of Founder Queens of Solenopsis invicta (Hymenoptera: Formici- 
dae) in Central Texas. Environmental Entomology, 20, 1024-1029. http://dx.doi.org/10.1093/ee/20.4.1024

[19] King, T.G. and Phillips Jr., S.A. (1992) Destruction of Young Colonies of the Red Imported Fire Ant by the Pavement Ant (Hymenoptera: Formicidae). Entomological News, 103, 72-77.

[20] Wojcik, D.P. (1994) Impact of the Red Imported Fire Ant on Native Ant Species in Florida. In: Williams, D.F., Ed., Exotic Ants Biology, Impact, and Control of Introduced Species, Westview Press, Boulder, 269-281.

[21] Rao, A. and Vinson, S.B. (2002) Invasion of Red Imported Fire Ant Nests by Selected Predatory Ants: Prospects of Utilizing Native Ants in Fire Ant Management. Southwestern Entomology, 25, 61-70.

[22] Rao, A. and Vinson, S.B. (2004) Ability of Resident Ants to Destruct Small Colonies of Solenopsis invicta (Hymenoptera: Formicidae). Environmental Entomology, 33, 587-598. http://dx.doi.org/10.1603/0046-225X-33.3.587

[23] Vinson, S.B. and Rao, A. (2004) Inability of Incipient Solenopsis invicta (Hymenoptera: Formicidae) Colonies to Establish in a Plot with a High Density of Solenopsis (Diplorhoptrum) Colonies. Environmental Entomology, 33, 16261631. http://dx.doi.org/10.1603/0046-225X-33.6.1626

[24] LeBrun, E.G., Abbott, J. and Gilbert, L.E. (2013) Imported Crazy Ant Displaces Imported Fire Ant, Reduces and Homogenizes Grassland Ant and Arthropod Assemblages. Biological Invasions, 15, 2429-2442. http://dx.doi.org/10.1007/s10530-013-0463-6

[25] Chen, J., Rashid, T., Feng, G., Zhao, L., Oi, D. and Dreese, B.M. (2013) Defensive Chemicals of Tawny Crazy Ants, Nylanderia fulva (Hymenoptera: Formicidae) and Their Toxicity to Red Imported Fire Ants, Solenopsis invicta (Hymenoptera: Formicidae). Toxicon, 76, 160-166. http://dx.doi.org/10.1016/j.toxicon.2013.09.018

[26] Banks, W.A., Lofgren, C.S., Jouvenaz, D.P., Stringer, C.E., Bishop, P.M., Williams, D.F., Wojcik, D.P. and Glancey, B.M. (1981) Techniques for Collecting, Rearing, and Handling Imported Fire Ants. USDA, SEA, AATS-S-21, 9 p.

[27] Valles, S.M. and Porter, S.D. (2003) Identification of Polygyne and Monogyne Fire Ant Colonies (Solenopsis invicta) by Multiplex PCR of Gp-9 Alleles. Insectes Sociaux, 50, 199-200. http://dx.doi.org/10.1007/s00040-003-0662-8

[28] Robertson, J.L., Savin, N.E., Preisler, H.K. and Russell, R.M. (2007) Bioassays with Arthropods. Second Edition, CRC Press, Baco Raton.

[29] Chen, J. (2009) Repellency of an Over-the-Counter Essential Oil Product from China against Workers of Red Imported Fire Ants. Journal of Agricultural and Food Chemistry, 57, 618-622. http://dx.doi.org/10.1021/jf8028072

[30] Chen, J., Cantrell, C.L., Duke, S.O. and Allen, M.L. (2008) Repellency of Callicarpenal and Intermedeol against Workers of Imported Fire Ants (Hymenoptera: Formicidae). Journal of Economic Entomology, 101, 265-271. http://dx.doi.org/10.1093/jee/101.2.265

[31] Appel, A.G., Gehret, M.J. and Tanley, M.J. (2004) Repellency and Toxicity of Mint Oil Granules to Red Imported Fire Ants (Hymenoptera: Formicidae). Journal of Economic Entomology, 97, 575-580. http://dx.doi.org/10.1093/jee/97.2.575

[32] Cheng, S.S., Liu, J.Y., Lin, C.Y., Hsui, Y.R., Lu, M.C., Wu, W.J. and Chang, S.T. (2008) Terminating Red Imported Fire Ants Using Cinnamomum osmophloeum Leaf Essential Oil. Bioresource Technology, 99, 889-893. http://dx.doi.org/10.1016/j.biortech.2007.01.039

[33] Drees, B.M. (2002) A New Technique for Laboratory Assessment of Red Imported Fire Ant Mound Drench Treatments. Southwestern Entomology, 27, 177-183.

[34] Nester, P.R. (2001) Evaluation of Citrex ${ }^{\circledR}$ Fire Ant Killer as Drench Treatment for Red Imported Fire Ant Mounds. http://global.oup.com/us/companion.websites/fdscontent/uscompanion/us/pdf/houp/15 4.pdf

[35] Flanders, K. (2015) 2015 Fire Ant Control Materials for Alabama Homeowners, ANR-0175-A. The Alabama Cooperative Extension System (Alabama A\&M University and Auburn University). https://store.aces.edu/ItemDetail.aspx?ProductID=13505\&SeriesCode=\&CategoryID=\&Keyword=ANR-0175-A

[36] Layton, B., McAdory, J. and Hudson, H. (2009) Effectiveness of Fire Ant Mound Treatment Products for Home Lawns. Midsouth Entomology, 3, 42-43.

[37] Kim, Y.W., Kim, M.J., Chung, B.Y., Bang du, Y., Lim, S.K., Choi, S.M., Lim, D.S., Cho, M.C., Yoon, K., Kim, H.S., Kim, K.B., Kim, Y.S., Kwack, S.J. and Lee, B.M. (2013) Safety Evaluation and Risk Assessment of D-Limonene. Journal of Toxicology and Environmental Health, Part B, Critical Reviews, 16, 17-38. http://dx.doi.org/10.1080/10937404.2013.769418

[38] Kramer, K.J., Beeman, R.W., Speirs, W.E., Burkholder, W.E. and McGovern, T.P. (1985) Effects of 2-Tridecanone and Analogues on the Reproduction and Mortality of Stored Product Insects. Journal of the Kansas Entomological Society, 58, 254-260.

[39] Lin, S.Y.H., Trumble, J.T. and Kumamoto, J. (1987) Activity of Volatile Compounds in Glandular Trichomes of Lycopersicon Species against Two Insect Herbivores. Journal of Chemical Ecology, 13, 837-850. http://dx.doi.org/10.1007/BF01020164 
[40] Braga, Y.F.B., Grangeiro, T.B., Freire, E.A., Lopes, H.L., Bezerra, J.N.S., Andrade-Neto, M. and Lima, M.A.S. (2007) Insecticidal Activity of 2-Tridecanone against the Cowpea Weevil Callosobruchus maculatus (Coleoptera: Bruchidae). Academia Brasileira de Ciências, 79, 35-39. http://dx.doi.org/10.1590/s0001-37652007000100005

[41] Williams, W.G., Kennedy, G.G., Yamamoto, R.T., Thacker, J.D. and Bordner, J. (1980) 2-Tridecanone: A Naturally Occurring Insecticide from the Wild Tomato Lycopersicon hirsutum f. glabratum. Science, 207, 888-889. http://dx.doi.org/10.1126/science.207.4433.888

[42] Weston, P.A., Johnson, D.A., Burton, H.T. and Snyder, J.C. (1989) Trichome Secretion Composition, Trichome Densities, and Spider Mite Resistance of 10 Accessions of Lycopersicon hirsutum. Journal of the American Society for Horticultural Science, 114, 492-498.

[43] Chatzivasileiadis, E.A. and Sabelis, M.W. (1997) Toxicity of Methyl Ketones from Tomato Trichomes to Tetranychus urticae Koch. Experimental and Applied Acarology, 21, 473-484. http://dx.doi.org/10.1023/A:1018436113892

[44] Antonious, G.F., Dahlman, D.L. and Hawkins, L.M. (2003) Insecticidal and Acaricidal Performance of Methylketones in Wild Tomato Leaves. Bulletin of Environmental Contamination and Toxicology, 71, 400-407. http://dx.doi.org/10.1007/s00128-003-0178-y

[45] Antonious, G.F. and Snyder, J.C. (2008) Tomato Leaf Crude Extracts for Insects and Spider Mite Control. In: Preedy, V.R. and Watson, R.R., Eds., Tomatoes and Tomato Products Nutritional, Medicinal and Therapeutic Properties, Science Publishers, Enfield, 269-297. http://dx.doi.org/10.1201/9781439843390-c13

[46] Burdock, G.A. (2010) Fenaroli’s Handbook of Flavor Ingredienta. Sixth Edition, CRC Press, Boca Raton.

[47] Ogunbinu, A.O., Ogunwande, I.A., Cioni, P.L. and Flamini, G. (2007) Eclipta indica L. (Asteraceae): A Source of 2Tridecanone. Journal of Essential Oil Research, 19, 362-363. http://dx.doi.org/10.1080/10412905.2007.9699306

[48] Antonious, G.F. (2004) Persistence of 2-Tridecanone on the Leaves of Seven Vegetables. Bulletin of Environmental Contamination and Toxicology, 73, 1086-1093. http://dx.doi.org/10.1007/s00128-004-0536-4

[49] Agency for Toxic Substances and Disease Registry (ATSDR) (2003) Toxicological Profile for Pyrethrins and Pyrethroids. US Department of Health and Human Services, Public Health Service, Atlanta.

[50] International Programme on Chemical Safety (1998) Concise International Chemical Assessment Document No. 5. Limonene. http://www.inchem.org/documents/cicads/cicads/cicad05.htm 